\title{
SPECTRAL REFLECTANCE-LITHOSTRATIGRAPHY OF TERRIGENOUS ROCKS OF THE PARNAIBA BASIN, BRAZIL: CHEMICAL COMPOSITION RELATIONSHIPS
}

\author{
LÊNIO S. GALVÂO* \& ICARO VITORELLO*
}

\begin{abstract}
RESUMO LITOESTRATIGRAFIA DE REFLECTÂNCIA ESPECTRAL DE ROCHAS TERRÍGENAS DA BACIA DO PARNAIBA, BRASIL: RELACIONAMENTOS COM A COMPOSIÇÂO QUIMICA As associagoes funcionais de espectros de reflectancia com constituintes de rochas sedimentares foram analisadas para sete unidades estratigrdficas da Bacia Paleoz6ica do Parnaiba, no nordeste do Brasil. Foram selecionadas vinte e seis amostras de testemunhos, para andlises qufmicas, de lamina delgada e de difragao de raios X. Fatores de ReflectSncia Bidirecional (BRF) foram obtidos em Iaborat6rio com dire96es de visada e ilumina9\$o pr6ximos ao nadir, na faixa do visfvel e infravermelho refletido $(400-2.500 \mathrm{~nm})$. A dependencia da BRF em relafao a composição qufmica foi avaliada para os seguintes constituintes: $\mathrm{SiO}_{2}, \mathrm{Al}_{2} \mathrm{O}_{3}$, ferro total (expresso como $\mathrm{Fe}_{2} \mathrm{O}_{3}$ ), $\mathrm{K}_{2} \mathrm{O}, \mathrm{MnO}, \mathrm{CaO}, \mathrm{MgO}, \mathrm{Na}_{2} \mathrm{O}, \mathrm{P}_{2} \mathrm{O}_{5}$ e $\mathrm{TiO}_{2}$. Adicionalmente, foram considerados o tamanho m6dio dos graos dos arenitos, o conteudo de carbono orgSnico total (TOC) e as razoes $\mathrm{SiO}_{2} / \mathrm{Al}_{2} \mathrm{O}_{3}, \mathrm{SiO}_{2} / \mathrm{Fe}_{2} \mathrm{O}_{3}$, e $\mathrm{Fe}_{2} \mathrm{O}_{3} / \mathrm{Al}_{2} \mathrm{O}_{3}$. As melhores correlagSes negativas com a reflectSncia foram obtidas para $\mathrm{Al}_{2} \mathrm{O}_{3}, \mathrm{Fe}_{2} \mathrm{O}_{3}$, materia orgSnica e razao $\mathrm{Fe} 2 \mathrm{O}_{3} / \mathrm{Al}_{2} \mathrm{O}_{3}$. As melhores correlagoes positivas foram obtidas para $\mathrm{SiO}_{2}$, razoes $\mathrm{SiO}_{2} / \mathrm{Fe}_{2} \mathrm{O}_{3}$ e $\mathrm{SiO}_{2} / \mathrm{Al}_{2} \mathrm{O}_{3}$. Muito embora componentes importantes como $\mathrm{SiO}_{2}, \mathrm{Al}_{2} \mathrm{O}_{3}$ e $\mathrm{K}_{2} \mathrm{O}$ nSo produzam absorfoes na faixa 400-2.500 nm, como produzem, por exemplo, os fons de ferro e carbono, o escrutmio dos graficos revelou o papel destas varidveis interdependentes no processo de espalhamento e absorcao. Um aumento de $\mathrm{SiO}_{2}$ e freqiientemente associado a maiores reflectSncias, enquanto o reverse 6 verdadeiro para $\mathrm{Al}_{2} \mathrm{O}_{3}$ e $\mathrm{K}_{2} \mathrm{O}$. Este estudo indica a necessidade de modelagens empfricas para a melhor compreensSo do processo de transferencia de radiacao.
\end{abstract}

Palavras-chave: ReflectSncia espectral, rochas sedimentares, composifao qufmica.

\begin{abstract}
Functional associations of reflectance spectra with sedimentary rock constituents were analyzed for seven stratigraphic units from the Paleozoic Parnaiba Basin, northeastern Brazil. Twenty six core samples were selected for chemical analysis, thin section description and X-ray diffraction. Bidirectional Reflectance Factors (BRF) were obtained in the laboratory with illumination-viewing directions near nadir, in the visible and reflectedinfrared intervals (400- to 2,500-nm). The dependence of the BRF on chemical composition was evaluated for the following constituents: $\mathrm{SiO}_{2}, \mathrm{Al}_{2} \mathrm{O}_{3}$, total iron (expressed as $\mathrm{Fe}_{2} \mathrm{O}_{3}$ ), $\mathrm{K}_{2} \mathrm{O}, \mathrm{MnO}, \mathrm{CaO}, \mathrm{MgO}, \mathrm{Na}_{2} \mathrm{O}, \mathrm{P}_{2} \mathrm{O}_{5}$, and $\mathrm{TiO}_{2}$. Additionally, we considered the average grain size of the sandstones, the total organic carbon content (TOC), and the $\mathrm{SiO}_{2} / \mathrm{Al}_{2} \mathrm{O}_{3}, \mathrm{SiO}_{2} / \mathrm{Fe}_{2} \mathrm{O}_{3}$ and $\mathrm{Fe}_{2} \mathrm{O}_{3} / \mathrm{Al}_{2} \mathrm{O}_{3}$ ratios. The best negative correlations of reflectance were obtained with $\mathrm{Al}_{2} \mathrm{O}_{3}, \mathrm{Fe}_{2} \mathrm{O}_{3}$, organic matter and $\mathrm{Fe}_{2} 6 \mathrm{yAl}_{2} \mathrm{O}_{3}$ ratio, and positive correlations with $\mathrm{SiO}_{2}, \mathrm{SiO}_{2} / \mathrm{Fe}_{2} \mathrm{O}_{3}$ and $\mathrm{SiO}_{2} /$ $\mathrm{Al}_{2} \mathrm{O}_{3}$ ratios. Even though major oxide constituents, such as $\mathrm{SiO}_{2}, \mathrm{Al}_{2} \mathrm{O}_{3}$ and $\mathrm{K}_{2} \mathrm{O}$, do not produce absorptions in the range of 400- to 2,500-nm as iron ions and carbon do, the scrutiny of the scatter diagrams provided some clues to the role played by these interdependent variables in surface and very near surface light scattering and absorption. An increase in $\mathrm{SiO}_{2}$ is often associated with higher reflectance, while the reverse is true for $\mathrm{Al}_{2} \mathrm{O}_{3}$ and $\mathrm{K}_{2} \mathrm{O}$. This study indicates the need of empirical modeling for a better comprehension of the radiation transfer process.
\end{abstract}

Keywords: Spectral reflectance, sedimentary rocks, chemical composition.

INTRODUCTION Reflectance minima on reported reflectance spectra of sedimentary rock samples are usually considered diagnostic features related to energy absorption by some of the rock minerals (Hovis \& Callahan 1966, Hunt \& Salisbury 1976, Conel et al 1980, Lang et al 1990). In terms of absorption mechanisms, within the spectral range of the visible - VIS (400- to 700-nm) and very near-infrared VNIR (700- to $1,000-\mathrm{nm}$ ), broad band absorption is predominantly related to electronic transition in metal ions, specially $\mathrm{Fe}^{3+}$ and $\mathrm{Fe}^{2+}$ of such minerals as hematite, goethite, and jarosite (Hunt 1977). For the short-wave infrared interval - SWIR (1,000- to 3,000-nm), absorption bands are associated with vibrational processes, such as those involving $\mathrm{H}_{2} \mathrm{O}, \mathrm{OH} \% \mathrm{CO}_{3^{-}}{ }^{2}$, and $\mathrm{SO}_{4}{ }^{\prime 2}$, in several minerals (e.g., kaolinite, smectite, muscovite, calcite, dolomite, gypsum).

In reality, the character of reflectance spectra for solid rock samples might be related to well-defined absorption bands, but sometimes the interpretations are of very dubious nature. Unfortunately, little is understood of the complex interactions of an incident photon in its trajectory through the rock material. However, some advances have been made in studies of the optical response of minerals as they relate to diagnostic absorption features (e.g., Sherman \& Waite 1985), the evaluation of the effects of varying the proportion of the mineral components (e.g., Johnson et al. 1983), the study of scattering theories (e.g., Hapke 1981), and their applications (e.g., Clark \& Roush 1984, and references therein).

Several studies (e.g., Adams \& McCord 1973, Dollfus et al. 1980, Sasaki et al. 1983, Hoffmann et al 1990,Jaumann 1991) have also indicated that oxide content correlates with the spectral properties of several geological materials. The importance of these results to our studies resides in the fact that in sedimentary rocks, composed of intermixed minerals, the gross chemical content is often an adequate representation of such multicomponent mineralogy and is easily and accurately determined. Despite these advances, the spectral properties of siliciclastic specimens are not well defined and no empirical or theoretical model exists for them. The determination of an adequate theory for predict- 
ing the radiation that returns from a sedimentary rock surface requires an improved knowledge of the role played in the scattering process by the physical and chemical properties of the surface, coarse and fine particles, the moisture and carbon content, and the illumination-viewing geometry.

In the present paper, we will examine the functional associations of bidirectional reflectance spectra (400- to 2,500-nm) with oxide composition, organic matter and the coarse grain size of 26 core samples, which are siliciclastic rocks from seven stratigraphic units. The samples were obtained from boreholes in the Paleozoic Parnafba Basin of northeastern Brazil (Fig. 1). The objective is to identify the most important rock and optical variables and what associations occur among them.

The approach is based on the concept of reflectancelithostratigraphy, which is the analysis of the relationships between the measured reflectance of samples and the bulk sedimentary rock characteristics. A practical example of this procedure occurs when cores from oil wells are photographed. In this case, the spectral behavior of the samples in the panchromatic visible interval (400- to $700-\mathrm{nm})$ is registered on a film (detector). However, these photographic observations do not take advantage of the infrared portion of the spectrum that contains important geologic information. The advantage of using spectroradiometers comes from the fact that high resolution spectral data can be easily acquired and mathematically manipulated in order to extract information from the samples not only in the visible region, but also in the infrared interval. The disadvantage is that spatial information (e.g., sedimentary structures) can not be adequately registered by such equipment. However, recent steps have been taken towards the development of scanners capable of producing multiple digital images of cores within the spectral range of the VIS, VNIR and SWIR (Kowalick et al. 1991).

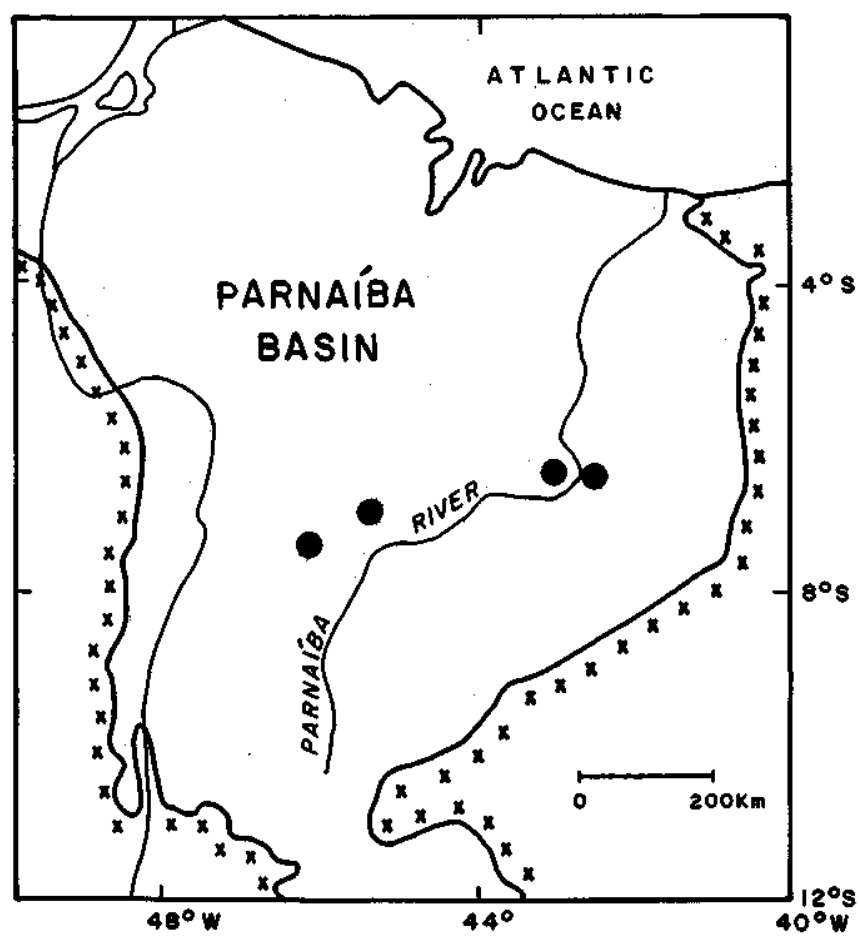

Figure 1-Map showing the location of the boreholes (dots) within the Parnaiba Basin (outlined by crosses) from where the samples for this work were obtained

Figura 1 - Mapa com a localiza?ao dos furos de sondagem (pontos) na Bacia do Parnaíba (limites indicados por cruzes), de onde foram obtidas as amostras deste trabalho
ANALYTICAL PROCEDURE Reflectance-lithoStratigraphy In terms of interactions with radiation, we can consider a sedimentary rock as a semi-infinite medium, optically anisotropic, with an irregular rough surface. Downward incident radiation will be scattered at the surface in an upward reflected component, and a downward diffuse flux penetrating into the sample. Each incident photon will change direction as it interacts with each individual grain boundary, and reflection, refraction and diffraction take place. The fraction that returns upwards depends on the roughness, the composition of the surface, and the wavelength. The specular reflectance, a major component of the up welling flux, will be dispersed as the photon comes off individual grains with randomly oriented surfaces. Ignoring polarization, a smoother surface will tend to enhance the specular component whereas a rougher surface will facilitate absorption and a diffuse reflectance instead of the specular reflectance. This same effect is clearly seen in "frosted" glass.

Diffuse reflectance is due to scattering at grain boundaries within the sample. Afterwards the photon may exit from the mineral grain. Internally, there is absorption and scattering and the internal result is an upward diffuse flux, which is obviously smaller than the downward flux because of absorption. Such an upward flux depends on the internal volume reflectance and the transmittance through the medium which, in turn, depends on the internal trajectory and the absorption characteristics of the material. The size, shape and arrangement of grains regulate the porosity and packing that affect the amount of back and forth transmittance between scattering boundaries and, consequently, the opportunity for absorption. Optically opaque rock materials (e.g., carbonaceous matter) are those that have strong scattering properties, defined by shorter transmission path lengths. In the near absence of absorption particles, translucent materials (e.g., clear quartz) have longer transmission path lengths. When translucent materials are irradiated, a maximum amount of light is scattered back out, which is increased for decreasing grain sizes. As sedi-mentary surfaces are irradiated, some radiance is scattered back or transmitted through the sample where it will undergo many more scattering events before exiting the surface. In different rock materials, diverse penetration depths, dictated by the number of scattering events and transmission path lengths, will provide variable absorption opportunities.

Therefore, the upward reflectance that reaches the sensor has a diffuse and a specular component that depends on the direction of the irradiance and of the viewing, the wavelength, and the superficial and internal optical characteristics. We can technically control all these variables except the latter. However, it should be emphasized that the measured reflectance indistinctly reflects the optical properties of the surface and the outermost layers of the rock, with a complicating factor that a siliciclastic rock can be relatively heterogeneous in grain size and composition.

Thus, the variations in the spectral curves of diverse sedimentary rocks, obtained under the above set of conditions, can then be correlated with the bulk sedimentary rock characteristics for lithostratigraphic purposes.

Bidirectional Reflectance Factor (BRF) Ideally, the Bidirectional Reflectance Distribution Function, that relates the directional radiance of the surface to the directional irradiance, would be used for the precise determination of the variations in spectral reflectance with angle. In practice, a viable alternative, that provides an estimated value of that function under the above requirements, is the Bidirectional Reflectance Factor (BRF). The BRF can be derived through a two step procedure that requires a Lambertian reference standard of known reflectance, and meas- 
urements for each geometric configuration. Taking care that the diffuse component of illumination be negligible, the BRF can be calculated from the ratio of the observed sample radiance by the reference standard radiance, identically irradiated, multiplied by the BRF of the reference (see Judd 1967, for the nomenclature).

Reflectance data collection Bidirectional Reflectance Factors (BRF) were obtained for 26 samples with an IRIS (Infra-Red Intelligent Spectroradiometer) that makes determinations at $2 \mathrm{~nm}$ intervals from 400 - to $1,000-\mathrm{nm}$ and at $4 \mathrm{~nm}$ intervals from $1,000-$ to $2,500-\mathrm{nm}$. A three point moving average was used to minimize uneven readings. Small illumination and viewing angles (less than $20^{\circ}$ ) provided a near nadir geometry in relation to the surface of the sedimentary sample and of the reference standard (a spectral on plate), sequentially illuminated by a $600 \mathrm{~W}$ tungsten lamp (Fig. 2). Furthermore, according to Hapke (1981), maximum contri-bution of the multiply scattered radiance component is atta-ined when surfaces are viewed and illuminated near the nadir.

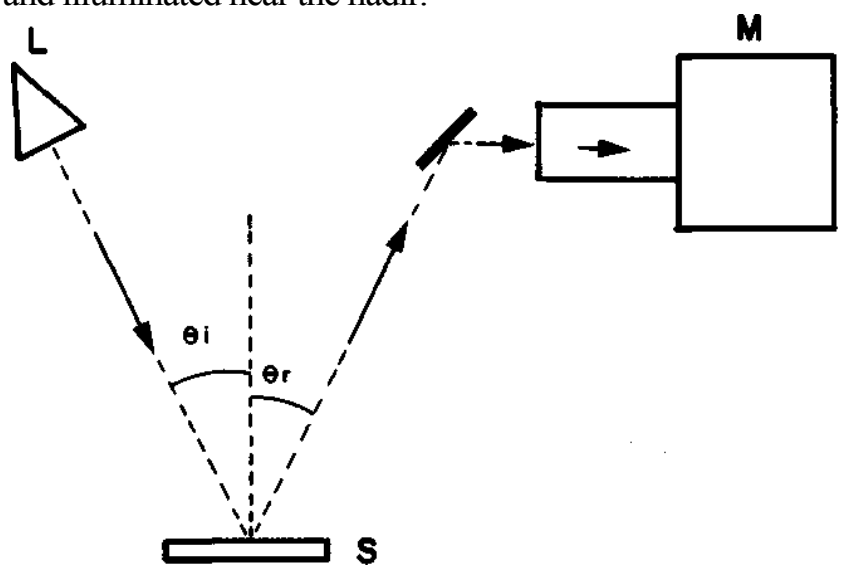

Figure 2 - General scheme for spectral reflectance data collection. The radiation strikes a horizontally uncovered sample (S). Arrows indicate the light path from the source $(L)$ and to a monochromater $(M)$, where detectors register the radiation reflected by the sample

Figura 2- Esquema geral para a coleta de dados de reflectancia eSpectral. A radiacao incide sobre a amostra (S) horizontalmente posicionada. As setas indicant a trajettfria da luz, a partir da fonte (L) ate" o monocromador (M), onde detetores registram a radia ${ }^{\wedge}$ ao refletida pela amostra

Care was also taken to minimize interference from scattered radiance from outside the instrument field of view. Because of the small and variable sizes and shapes of the samples (sawed disks of less than $10 \mathrm{~cm}$ in diameter), and the strong illumination, adjacency effects might become a very serious problem. Both faces of each sample were measured 3 or 4 times in slightly different view areas. Visual examination of the sawed-off face shows a smoother and brighter surface than the naturally open fresh surfaces, specially for sandstones. Also, almost imperceptible saw-induced orientation was observed in the face of some samples.

Bulk geochemical analyses A small portion of each sample, separated for chemical analyses, was pulverized and sieved through a 150 mesh screen. The weight percent of $\mathrm{SiO}_{2}, \mathrm{Al}_{2} \mathrm{O}_{3}$, total iron (henceforth expressed as $\mathrm{Fe}_{2} \mathrm{O}_{3}$ ), $\mathrm{CaO}, \mathrm{MgO}, \mathrm{K}_{2} \mathrm{O}, \mathrm{MnO}, \mathrm{TiO}_{2}$, and $\mathrm{P}_{2} \mathrm{O}_{5}$, were determined by ICP (Inductively Coupled Plasma), and $\mathrm{Na}_{2} \mathrm{O}$ by atomic absorption spectroscopy.

\section{Borehole samples from the Parnafba Basin The}

Parnafba Basin is an oval shaped basin of predominantly

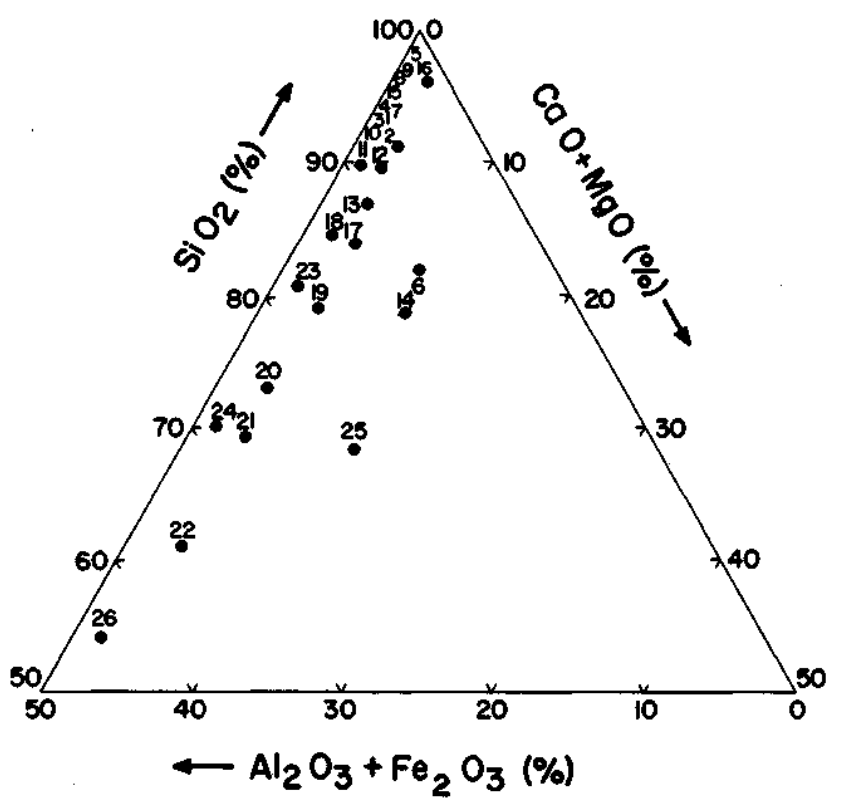

Figure 3-Schematic triangular diagram of the terrigenous admixture of 26 rock samples from the Parnafba Basin. The numbers represent the samples described in table 1

Figura 3 - Diagrama temaiio esquematico das 26 amostras da Bacia do

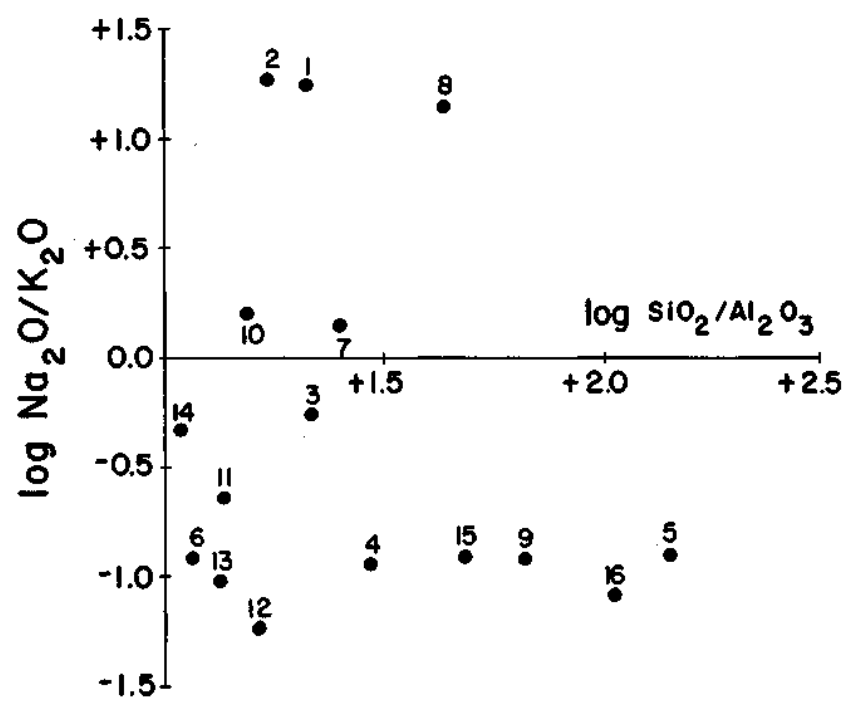

Parnafba. Os numeros representam as amostras descritas na tabela 1 Figure 4 - Plot of the log $\mathrm{SiO}_{2} / \mathrm{Al}_{2} \mathrm{O}_{3}$ versus the $\log \mathrm{Na}_{2} \mathrm{O} /$ $\mathrm{K}_{2} \mathrm{O}$ for the 16 sandstone samples

Figura 4 - Variafoes do $\log \mathrm{SiO} / \mathrm{Al}_{2} \mathrm{O}_{3}$ e do $\log \mathrm{Na}_{2} \mathrm{O} / \mathrm{K}_{2} \mathrm{O}$ para as 16 amostras de arenito

Paleozoic terrigenous sediments, located in northeastern Brazil. The sedimentary column of about 3000 meters is a sequence of alternating sandstones, siltstones and shales from the Silurian to the Permian. The predominance of the coarser components, where fossils are usually absent, makes the Parnafba sequence ideal for testing the approach of the present paper. The 26 sawed disk samples were selected from seven stratigraphic units of four boreholes located in a $400 \mathrm{~km}$ linear length, in the southeastern part of the basin (Fig. 1). The units are Serra Grande, Itaim, Pimenteira, Cabegas, Longf, Poti and Pedra de Fogo. The samples are shortly described in table 1 , based on hand specimen examination, thin section descriptions and X-ray diffraction for clay mineral identification in some samples. 
Table 1 - Description of the sedimentary rock samples, based on hand specimen observation, thin section description and $X$-ray diffraction for clay mineral identification

Tabela 1 - Descri?ao das amostras de rochas sedimentares, baseado em observa9oes de amostras, descrifoes de laminas delgadas e difra?ao de raios X, para a identifica9§o de minerals de argilas.

\begin{tabular}{|c|c|c|}
\hline Sample & Description & Unit \\
\hline 01 & Very fine grained light pink sandstone; & Serra Grande \\
\hline 02 & Fine grained sandstone with quartz (80\%) and feldspars $(16 \%)$ & Itaim \\
\hline 03 & Medium grained light colored sandstone with quartz $(63 \%)$, microcline $(28 \%)$ and orthoclase $(5 \%)$; & Serra Grande \\
\hline 04 & Fine grained light gray sandstone with quartz $(88 \%)$ and orthoclase $(5 \%)$ & Poti \\
\hline 05 & Fine grained white sandstone; & Pimenteira \\
\hline 06 & $\begin{array}{l}\text { Medium grained sandstone with quartz }(70 \%) \text {, dolomite }(10 \%) \text {, orthoclase }(8 \%) \text {, } \\
\text { plagioclase }(5 \%) \text { and microcline }(5 \%) \text {; }\end{array}$ & Poti \\
\hline 07 & Fine grained light gray sandstone with quartz $(60 \%)$ and plagioclase $(15 \%)$ & Itaim \\
\hline 08 & Medium grained light gray sandstone with quartz (85\%) and orthoclase (10\%); & Serra Grande \\
\hline 09 & Medium grained light gray sandstone with quartz $(65 \%)$ and orthoclase $(5 \%)$ & Serra Grande \\
\hline 10 & Very fine grained light gray sandstone with quartz $(40 \%)$, microcline $(10 \%)$ and plagioclase $(8 \%)$ & Itaim \\
\hline 11 & Fine grained light gray sandstone; & Poti \\
\hline 12 & Fine grained light gray sandstone; & Poti \\
\hline 13 & Fine grained light brown sandstone; & Poti \\
\hline 14 & $\begin{array}{l}\text { Very fine grained light gray sandstone with quartz }(77 \%) \text {, dolomite }(10 \%) \text {, } \\
\text { k-feldspar }(5 \%) \text { and plagioclase }(5 \%) \text {; }\end{array}$ & Poti \\
\hline 15 & Fine grained gray sandstone; & Serra Grande \\
\hline 16 & Medium grained gray sandstone with quartz (88\%), plagioclase $(6 \%)$ and orthoclase $(5 \%)$ & Cabeças \\
\hline 17 & Gray mudstone; & Poti \\
\hline 18 & Red mudstone; & Pedra de Fogo \\
\hline 19 & Dark shale with silt laminations; clay minerals are illite/smectite and illite/chlorite interlayered; & Cabeças \\
\hline 20 & Dark shale; & Poti \\
\hline 21 & Dark shale with silt laminations; illite predominates over chlorite; & Pimenteira \\
\hline 22 & Black shale; & Serra Grande \\
\hline 23 & Dark shale; illite predominates over chlorite; & Longa \\
\hline 24 & Dark shale with sitt laminations; presence of illite, chlorite and illite/smectite interlayered; & Pimenteira \\
\hline 25 & Blake sale; clay minerals are illite and chlorite; & Cabeças \\
\hline 26 & Laminated dark shale & Pimenteira \\
\hline
\end{tabular}

Table 2 - Correlation matrix for the chemical constituents (wt. \%) of 26 sedimentary rock samples. TOC stands for total organic carbon

Tabela 2 - Matriz de correlasao para constituintes quimicos (\%) de 26 amostras de rochas sedimentares. TOC representa o conteudo de carbono orgSnico total

\begin{tabular}{|c|c|c|c|c|c|c|c|c|c|c|c|}
\hline & $\mathrm{SiO}_{2}$ & $\mathrm{Al}_{2} \mathrm{O}_{3}$ & $\mathrm{CaO}$ & $\mathrm{MgO}$ & $\mathrm{Fe}_{2} \mathrm{O}_{3}$ & MnO & $\mathrm{P}_{2} \mathrm{O}_{3}$ & $\mathrm{TiO}_{2}$ & $\mathrm{~K}_{2} \mathrm{O}$ & $\mathrm{Na}_{2} \mathrm{O}$ & TOC \\
\hline $\mathrm{SiO}_{2}$ & 1.00 & -0.96 & -0.22 & -0.70 & -0.84 & -0.15 & -0.31 & -0.37 & -0.80 & -0.13 & -0.56 \\
\hline $\mathrm{Al}_{2} \mathrm{O}_{3}$ & & 1.00 & 0.09 & 0.61 & 0.85 & -0.04 & 0.23 & 0.23 & 0.75 & 0.16 & 0.63 \\
\hline $\mathrm{CaO}$ & & & 1.00 & 0.22 & 0.05 & 0.27 & 0.17 & 0.29 & 0.04 & -0.09 & 0.33 \\
\hline $\mathrm{MgO}$ & & & & 1.00 & 0.40 & 0.65 & 0.48 & 0.76 & 0.61 & 0.18 & 0.47 \\
\hline $\mathrm{Fe}_{2} \mathrm{O}_{3}$ & & & & & 1.00 & -0.06 & 0.13 & 0.22 & 0.57 & -0.07 & 0.37 \\
\hline $\mathrm{MnO}$ & & & & & & 1.00 & 0.50 & 0.84 & 0.09 & 0.14 & -0.09 \\
\hline $\mathrm{P}_{2} \mathrm{O}_{3}$ & & & & & & & 1.00 & 0.48 & 0.29 & -0.02 & 0.12 \\
\hline $\mathrm{TiO}_{2}$ & & & & & & & & 1.00 & 0.22 & 0.17 & 0.16 \\
\hline $\mathrm{K}_{2} \mathrm{O}$ & & & & & & & & & 1.00 & 0.05 & 0.51 \\
\hline $\mathrm{Na}_{2} \mathrm{O}$ & & & & & & & & & & 1.00 & 0.09 \\
\hline TOC & & & & & & & & & & & 1.00 \\
\hline
\end{tabular}

The major chemical constituents of these samples are shown in the three component diagram of figure 3 . In a terrigenous admixture, the $\mathrm{SiO}_{2}$ end member can represent the amount of sand and silt quartz grains; the $\mathrm{Al}_{2} \mathrm{O}_{3}+\mathrm{Fe}_{2} \mathrm{O}_{3}$ component can be related to the clay matrix and clay mineral component; and the $\mathrm{CaO}+\mathrm{MgO}$ end member can repre-sent the chemical cement material. The interpretation based on the sample distribution of figure 3 indicates that our samples range from claystones and clay shales in the direc-tion of the
$\mathrm{Al}_{2} \mathrm{O} 3-\mathrm{Fe}_{2} \mathrm{O}_{3}$ end (low silica and high aluminum and iron) to the mature sandstones near the $\mathrm{SiO}_{2}$ end. Most of the samples have low amounts of carbonates, except samples 6,14 and 25 (see table 1 for sample description).

The maturity of the sandstones can also be interpreted from the ratio of the $\log \mathrm{SiO}_{2} / \mathrm{Al}_{2} \mathrm{O}_{3}$ to the $\log \mathrm{Na}_{2} \mathrm{O} / \mathrm{K}_{2} \mathrm{O}$, shown in figure 4. Mature sandstones (quartz arenites) would have high $\mathrm{SiO}_{2} / \mathrm{Al}_{2} \mathrm{O}_{3}$ ratios indicating the predominance of quartz grains and not much clay matrix or 

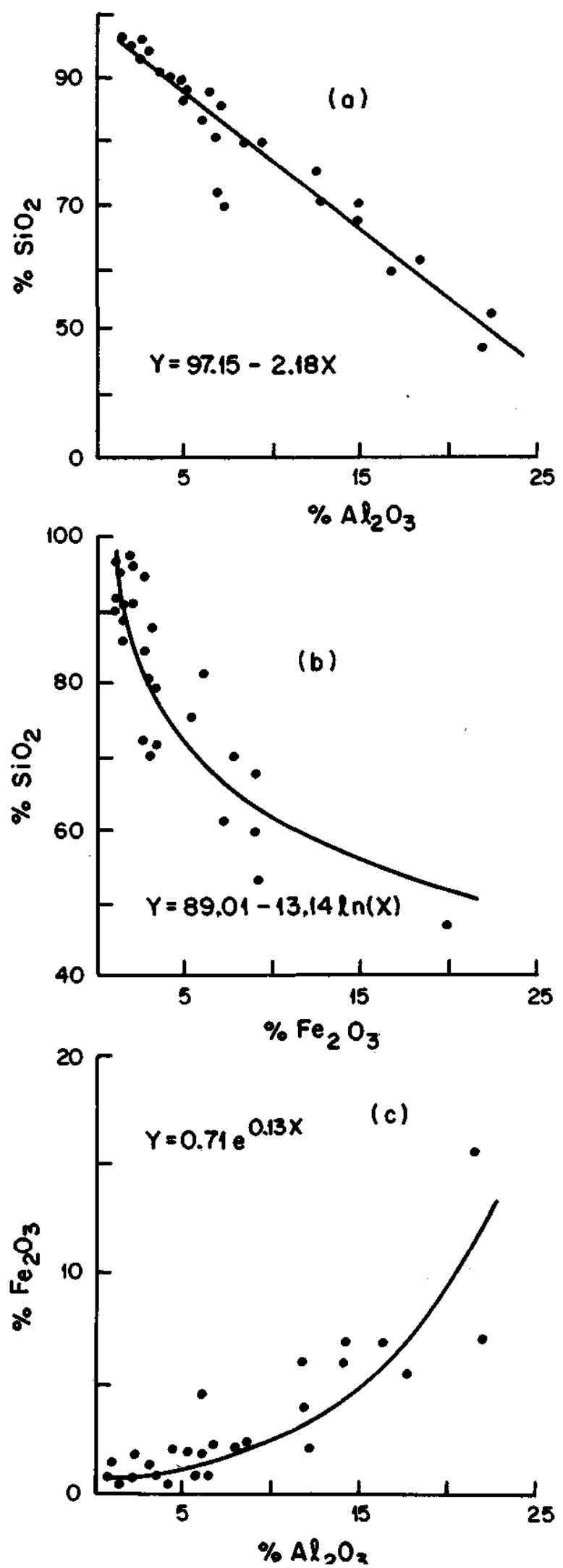

Figure 5 - Scatter diagrams for the 26 sandstone and shale samples, illustrating the relationships between $\mathrm{SiO}_{2}$ and $\mathrm{Al}_{2} \mathrm{O}_{3}$ in (a), $\mathrm{SiO}_{2}$ and $\mathrm{Fe}_{2} \mathrm{O}_{3}$ in (b), and between $\mathrm{Fe}_{2} \mathrm{O}_{3}$ and $\mathrm{Al}_{2} \mathrm{O}_{3}$ in (c)

Figura 5 - Diagrama para 26 amostras de arenitos e folhelhos, ilustrando as relasoes entre $\mathrm{SiO}_{2}$ e $\mathrm{Al}_{2} \mathrm{O}_{3}$ em (a), $\mathrm{SiO}_{2} \mathrm{eFe}_{2} \mathrm{O}_{3}$ em (b), e entre $\mathrm{Fe}_{2} \mathrm{O}_{3}$ e $\mathrm{Al}_{2} \mathrm{O}_{3}$ $\mathrm{em}(\mathrm{c})$ cement (e.g., samples 5, 16, 9, 15). Less mature are the feldspathic rocks (arkoses, subarkoses), that show low $\mathrm{SiO}_{2} / \mathrm{Al}_{2} \mathrm{O}_{3}$ ratios because of higher clay cement and detrital Al-silicate content (e.g., samples 14, 11, 6, 13). Along the $\mathrm{Na}_{2} \mathrm{O} / \mathrm{K}_{2} \mathrm{O}$ axis, the higher ratios $\left(\mathrm{Na}_{2} \mathrm{O} / \mathrm{K}_{2} \mathrm{O}\right)$ represent feldspathic graywackes (e.g., samples 2, 1, 8).

The examination of our samples in table 1 reveals that they belong to two kindred groups, which are the "sandstones", samples 1 to 16 , composed of quartz arenites, subarko-ses and arkoses, and the "shales", from 17 to 26, composed of mudstones and silt- and clay-shales. In these samples, the silica (Fig. 3) is present mainly as detrital quartz. Hematite $\left(\mathrm{Fe}_{2} \mathrm{O}_{3}\right)$ and goethite $(\mathrm{FeO} . \mathrm{OH})$ probably occur admixed with clays. In the shale group, besides silt-sized detrital quartz, the common minerals are illite and chlorite whose formation are usually enhanced by diagenesis.

RESULTS AND DISCUSSION Chemical constituents relationships Table 2 presents the correlation matrix for 11 variables (10 chemical components plus organic matter content of 26 core samples). According to the linear correlation values, as the $\mathrm{SiO}_{2}$ content increases, the content of the other constituents decreases, specially $\mathrm{Al}_{2} \mathrm{O}_{3}$, $\mathrm{MgO}, \mathrm{Fe}_{2} \mathrm{O}_{3}, \mathrm{~K}_{2} \mathrm{O}$ and $\mathrm{OM}$. This is an expected result because our samples gradually range from "clean" sandstones to shales (Fig. 3), as detrital quartz fraction decreases and the clay fraction increases. Carbonaceous material and $\mathrm{K}_{2} \mathrm{O}$ are abundant in shales.

The best $\mathrm{SiO}_{2}$ negative correlations are obtained with $\mathrm{A}_{2} \mathrm{O}_{3}(\mathrm{r}=-0.96), \mathrm{Fe}_{2} \mathrm{O}_{3}(\mathrm{r}=-0.84)$, and $\mathrm{K}_{2} \mathrm{O}(\mathrm{r}=-0.80)$. $\mathrm{Fe}_{2} \mathrm{O}_{3}$ and $\mathrm{Al}_{2} \mathrm{O}_{3}$ show the best positive correlation $(\mathrm{r}=0.85)$. Figure 5 exemplifies some of these relationships, and it can be noticed from this figure that a linear fit is not always the best representation of the relationship. For example, the best fit regression between $\mathrm{Fe}_{2} \mathrm{O}_{3}$ and $\mathrm{Al}_{2} \mathrm{O}_{3}$ (Fig. 5c) is expressed by an exponential curve. Such positive association suggests that most of the iron might be in the clay structure.

The diagram of figure 6 is also of interest. It presents the ratio $\mathrm{Fe}_{2} \mathrm{O}_{3} \mathrm{Al}_{2} \mathrm{O}_{3}$ against the ratio $\mathrm{SiO}_{2} / \mathrm{Al}_{2} \mathrm{O}_{3}$ for the sandstone samples. The mean and the deviation of shale samples are also shown in this figure for comparison with the sandstone dispersion. Sedimentary maturity is indicated by an increase in the ratio along the ordinate. The linear regression (correlation coefficient of 0.83 ) indicates that an increase in maturity corresponds to increasingly higher $\mathrm{Fe}_{2} \mathrm{O}_{3}$ content relative to $\mathrm{Al}_{2} \mathrm{O}_{3}$.

\section{BRF and chemical composition relationships}

The reflectance spectra of some samples of sandstones and shales are shown in figure 7. In general, shales have lower albedo than sandstones, because of the presence of relatively large amount of organic matter (Hunt \& Salisbury 1976). The featureless spectrum 22 in figure 7 is a typical example of a carbonaceous black shale, where the presence of opaque carbonaceous material masks absorption bands due to other components. Shales that contain relatively small amounts of total organic carbon (TOC) (e.g., spectrum 20 in Fig. 7) display higher albedo and more well-defined absorption bands.

Spectra of sandstones from the Parnaiba Basin generally show 1,400-, 1,900-, and 2,200-nm bands probably due to hydroxyl and molecular water. Sometimes, 1,400-1,410 nm and 2,160-2,200 $\mathrm{nm}$ band pairs indicate the presence of kaolinite in the samples (see, for example, spectrum 4 in Fig. 7). Features around $2,300 \mathrm{~nm}$, due to $\mathrm{CO}_{3}^{-2}$, are more difficult to be observed, because of the presence of only small amounts of carbonate material in the samples.

Features short of $1,000 \mathrm{~nm}$ usually result from the presence of iron oxide phases (Townsend 1987). In figure 7 , 


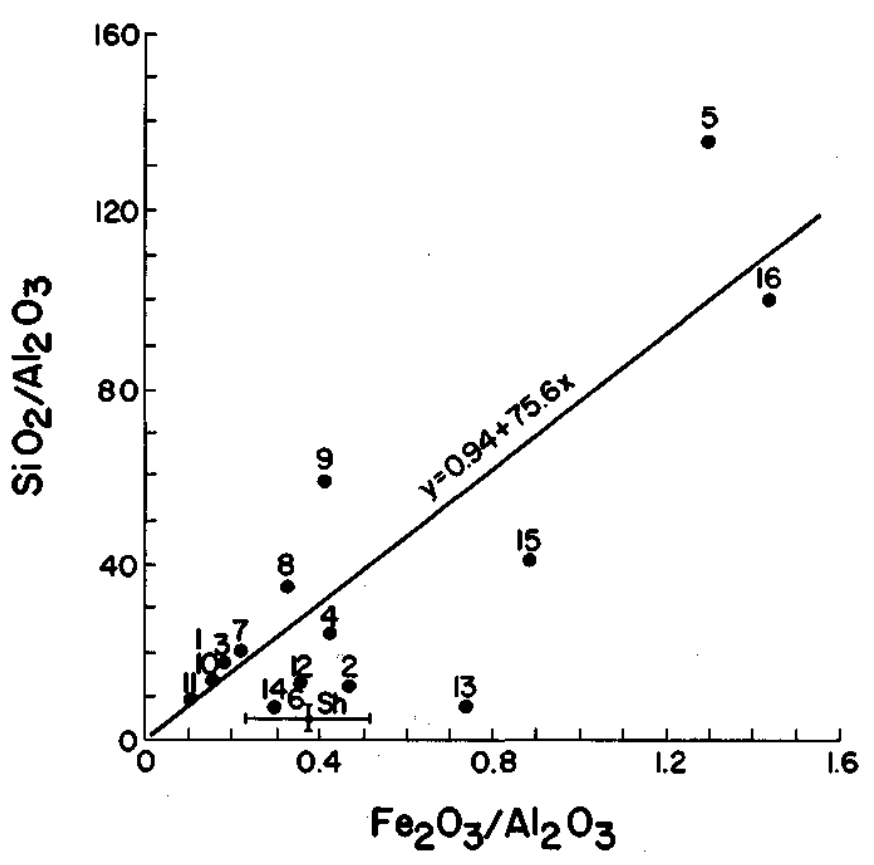

Figure 6 - Scatter diagram for 16 sandstone samples, showing the association between $\mathrm{Fe}_{2} \mathrm{O} / \mathrm{Al}_{2} \mathrm{O}_{3}$ and $\mathrm{SiO}_{2}$ / $\mathrm{Al}_{2} \mathrm{O}_{3}$ ratios. The mean (solid circle) and deviation (bars) for 10 shale samples (Sh) is also indicated Figura 6 - Diagrama para 16 amostras de arenitos, mostrando a associate entre as razoes $\mathrm{Fe}_{2} \mathrm{O}_{3} / \mathrm{Al}_{2} \mathrm{O}_{3}$ e $\mathrm{SiO}_{2} \mathrm{Al}_{2} \mathrm{O}_{3}$. A média (cfrculo escuro) e 0 desvio-padrao (barras) para as 10 amostras de folhelhos estao tambem indicados

Figure 7 - Bidirectional Reflectance Factors (BRF) for a few samples of shale (spectra 22, 20, 17) and of sandstone

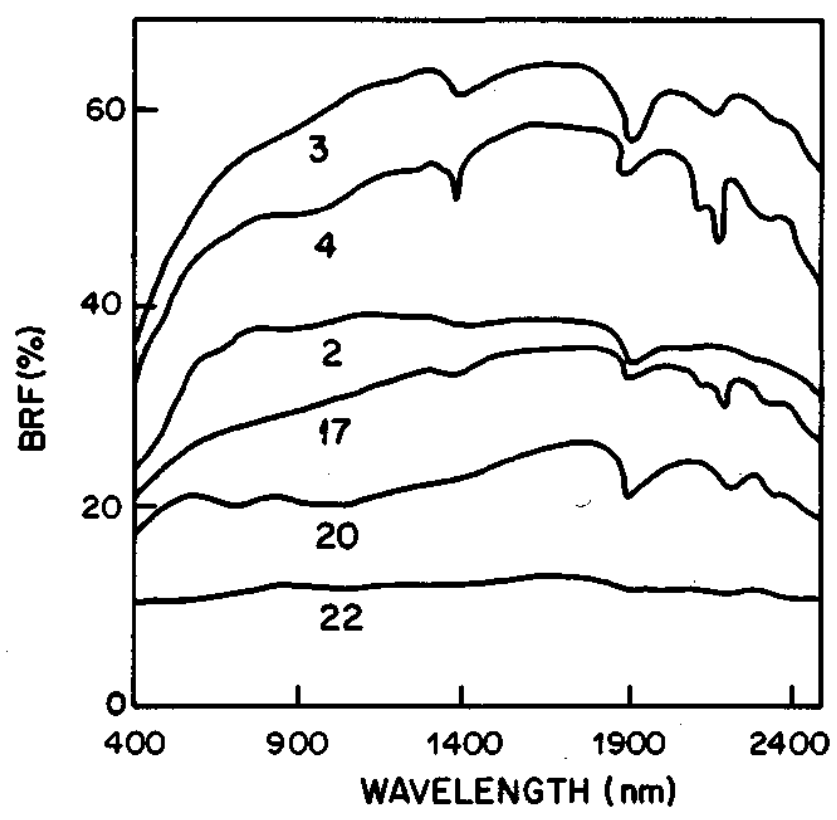

(spectra 2, 4, 3). The samples are described in table 1 under the same reference numbers

Figura 7 - Fator de ReflectaHcia Bidirecional (BRF) para algumas amostras de folhelhos (espectros 22, 20, 17) e arenitos (espectros 2, 4, 3). As amostras estao descritas na tabela 1 pelos mesmos numeros indicados the observed iron features include a weak absorption band at $650 \mathrm{~nm}$ (e.g., spectra 20 and 2) and a Fe ${ }^{3+}$ broad band effect at $900 \mathrm{~nm}$ (e.g., spectrum 4). The steep reflectance falloff, from the red to the blue wavelength $(650-$ to $450-\mathrm{nm})$, is another common iron feature observed in many spectra (e.g., spectrum 2).

For each spectrum, we obtained the values of reflectance at $25 \mathrm{~nm}$ intervals from $400-$ to $2,500-\mathrm{nm}$. They were used to establish correlations with the chemical constituents $\left(\mathrm{SiO}_{2}, \mathrm{Al}_{2} \mathrm{O}_{3}, \mathrm{Fe}_{2} \mathrm{O}_{3}, \mathrm{CaO}, \mathrm{MgO}, \mathrm{K}_{2} \mathrm{O}, \mathrm{MnO}\right.$, $\left.\mathrm{TiO}_{2}, \mathrm{P}_{2} \mathrm{O}_{5}\right)$, with some chemical ratios $\left(\mathrm{SiO}_{2} / \mathrm{Al}_{2} \mathrm{O}_{3}, \mathrm{SiO}_{2} /\right.$ $\mathrm{Fe}_{2} \mathrm{O}_{3}, \quad \mathrm{Fe}_{2} \mathrm{O}_{3} / \mathrm{Al}_{2} \mathrm{O}_{3}$ ), and with total organic carbon (TOC). The relationships of reflectance with composition parameters were analyzed for three groups of samples: sandstones $(\mathrm{n}=16)$, shales $(\mathrm{n}=10)$, and sandstones plus shales $(\mathrm{n}=26)$.

Figure 8 shows, in diagrams a, b and $\mathrm{c}$, representative correlations of reflectance for the sandstones, shales, and for both, respectively. In each diagram, correlation curves for some constituents have been omitted for an adequate graphic representation. For a given wavelength and chemical variable, positive correlations indicate that reflectance tends to be higher for samples with relatively greater amounts of the chemical constituent under analysis. On the other hand, negative correlations indicate an increase in reflectance associated with a decrease in the chemical content of the analyzed constituent, and vice-versa.

For sandstones (Fig. 8a), the overall correlation is better in the VIS and VNIR and gets worse in the SWIR. Among individual chemical constituents, $\mathrm{Fe}_{2} \mathrm{O}_{3}$ has the higher negative correlation. For the chemical ratios, the best results are for $\mathrm{Fe}_{2} \mathrm{O}_{3} / \mathrm{Al}_{2} \mathrm{O}_{3}$ (negative correlation) and $\mathrm{SiO}_{2} / \mathrm{Fe}_{2} \mathrm{O}_{3}$ (positive). The first relationship probably expresses the decrease in reflectance with an increase in the content of opaques. The positive association between reflectance and $\mathrm{SiO}_{2} / \mathrm{Fe}_{2} \mathrm{O}_{3}$ could be due to an increase in the quartz fraction over the iron associated with opaques or clay minerals.

For shales (Fig. 8b), an interesting result is the negative correlation peak for organic matter (TOC) in the VIS part (around $600 \mathrm{~nm}$ ). This result is in agreement with those obtained by Rowan et al. (1992), that indicated the channel2 of Landsat-TM (520-600 nm) as the best channel to estimate organic carbon contents. According to Meneses (1986), small TOC variations in carbonate rocks from Serra do Ramalho, northeastern Brazil, are responsible for a significant attenuation in their reflectance.

When all the samples (sandstones and shales) are considered (Fig. 8c), the highest correlations are for $\mathrm{A}_{2} \mathrm{O}_{3}$, TOC and $\mathrm{Fe}_{2} \mathrm{O}_{3}, \mathrm{SiO}_{2}$ and $\mathrm{SiO}_{2} / \mathrm{Fe}_{2} \mathrm{O}_{3}$ ratio present positive corre-lations. The use of all samples tends to flatten and smooth out variations in the correlations as a function of wavelength, in comparison with the sandstone and shale groups alone (Figs. $8 \mathrm{a}$ and $8 \mathrm{~b}$ ). Such fact indicates the importance of distinct analysis for each large sedimentary group.

To better visualize the reflectance behavior, a series of scatter diagrams were constructed for the most important variables, based on the results expressed in figure 8. For the sandstone group, the increase of reflectance $(900 \mathrm{~nm})$ in relation to an increase in $\mathrm{SiO}_{2} / \mathrm{Fe}_{2} \mathrm{O}_{3}$ ratio is shown in figure $9 \mathrm{a}$, and the decrease of reflectance $(600 \mathrm{~nm})$ in relation to an increase in $\mathrm{Fe}_{2} \mathrm{O}_{3} / \mathrm{Al}_{2} \mathrm{O}_{3}$ ratio is illustrated in figure $9 \mathrm{~b}$.

For the shale group, the decrease in reflectance $(600 \mathrm{~nm})$ related to the increase in organic matter can be seen in figure 10. Figures 1la and lib present the negative relationship of reflectance $(600 \mathrm{~nm}) v s$. TOC and the positive association of reflectance $(900 \mathrm{~nm})$ vs. $\mathrm{SiO}_{2} / \mathrm{Fe}_{2} \mathrm{O}_{3}$ ratio for the total set of samples, respectively. 

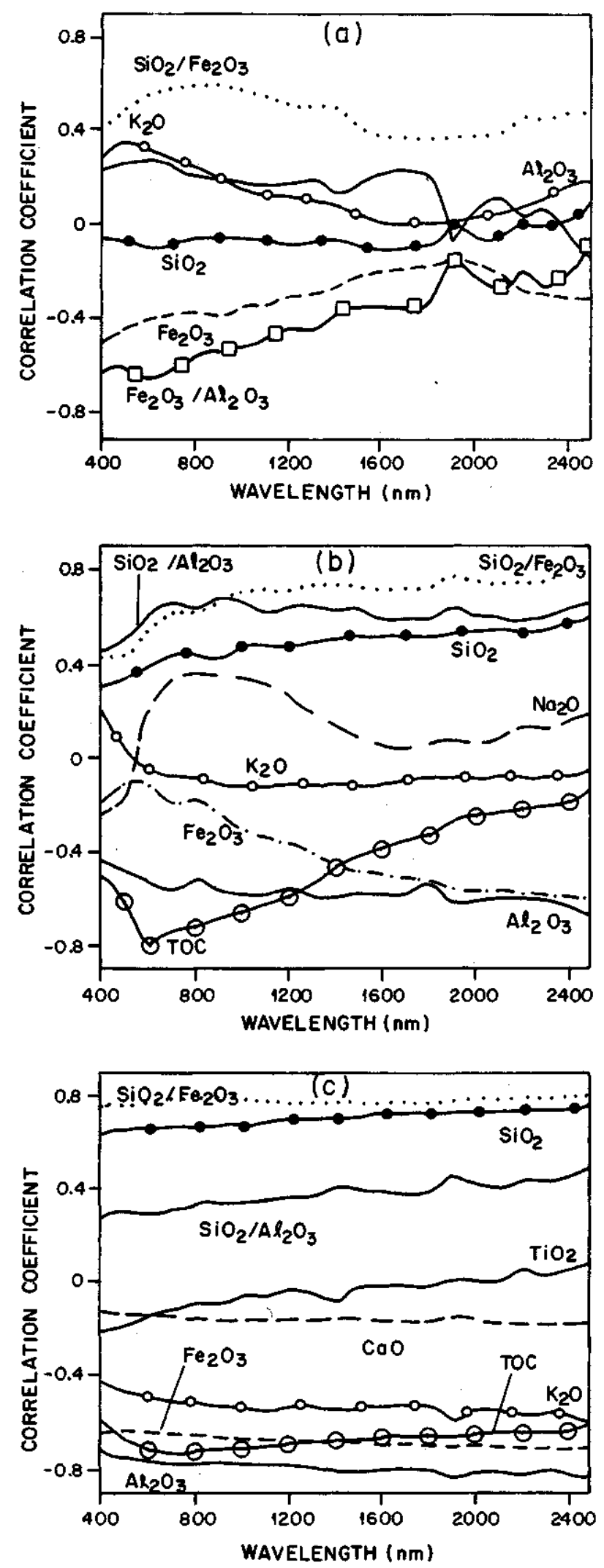

Figure 8-Correlation coefficient variation of reflectance with chemical variables, as a function of wavelength, for 16 sandstone samples in (a), 10 shale samples in (b), and for both in (c)

Figura 8 - Variação do coeficiente de correlac.ao da reflect§ncia e algumas variaVeis quf micas, em funjao do comprimento de onda, para 16 amostras de arenitos em (a), 10 amostras de folhelhos em (b), e para ambas em (c)
Observe that, in figures 9,10 and 11 , the best relationships have been accomplished with non-linear regressions.

BRF and organic content Carbonaceous matter is a spectrally opaque material that strongly reduces reflectance and obscures absorption band features. The presence of organic matter drastically diminishes the overall reflectance to a very low and featureless spectrum (e.g., spectrum 22 in Fig. 7).

In figure $8 \mathrm{~b}$ (shale samples), a negative correlation peak between reflectance and TOC is observed in the VIS region, around $600 \mathrm{~nm}$. The scatter diagram for this wavelength is shown in figure 10 . In the VIS interval of figure $8 \mathrm{~b}$, the correlation of reflectance with iron is the lowest, but becomes stronger towards the SWIR portion of the electromagnetic spectrum. This behavior is similar to that reported by Galvao (1994) on the spectral blanketing effect of organic matter over iron in soil samples from southeastern Brazil. In other words, in the visible region, i.e., in the portion of colors domain, iron is a spectrally important constituent only for samples with small amounts of organic matter.

However, it seems that the average TOC content of $0.03 \%$ and the small variations associated with the 16 sandstones samples from the Parnaiba Basin are not sufficient to pro-duce strong modifications in their spectra. Correlations between reflectance and TOC present poor results. Sandstones show a relatively larger reflectance dispersion (e.g., $54.3 \% \pm 9.0$ at $1500 \mathrm{~nm}$ ) in relation to the TOC dispersion $(0.03 \% \pm 0.01)$, whereas the shales present a very large TOC dispersion $(0.39 \% \pm 0.32)$ but a smaller reflectance scatter (e.g., $21.1 \% \pm 7.5$ at $1500 \mathrm{~nm}$ ) (Fig. 10).

BRF and grain size For the present discussion, we will assume that a siliciclastic rock is a simple mixture of coarse grains (framework) coexisting with the matrix, extremely fine grains (less than 4 microns). This assumption is dictated by our inability to view the real microscopic surface and internal structure and our inadequate technique of grain size measurement.

Figure 12 shows the distribution, in relation to the albedo, of the estimated mean diameter of coarser grains (quartz and feldspars), obtained from visual microscopic inspection of thin sections of sandstones. The size deviations from the mean are usually large. For this paper, the albedo can be understood as the overall reflectance in the 400 - to 2500-nm range. For example, in figure 7, the albedo is increasingly higher from spectrum 22 to spectrum 3, i.e., from shales to sandstones. In figure 12 , this spectral parameter is represented by the first score (PCI) resulting from a Principal Components Analysis applied to the total set of 26 spectra, and increases from negative to positive PCI score values. The quantitative approach used to calculate these scores is similar to that presented by Galvao et al. (1994) for analysis of laterite spectra.

The examination of the graphical plot of figure 12 suggests a conjunct increase in albedo and grain size, specially if we consider the estimated values of shales, plotted in figure 12 as a mean and the respective bars for the deviation. Conversely, the literature indicates that a decrease in grain size tends to increase the overall reflectance (Hunt 1977). When we consider only the 16 sandstone samples, the positive relationship is not so clear, and poor correlations between reflectance and grain size are obtained, in the range of 400- to $2500-\mathrm{nm}$. However, better correlations are obtained for the total set of 26 samples (sandstones plus shales). In fact, the positive correlation obtained in this case does not express the increase of reflectance with the increase in grain size, 

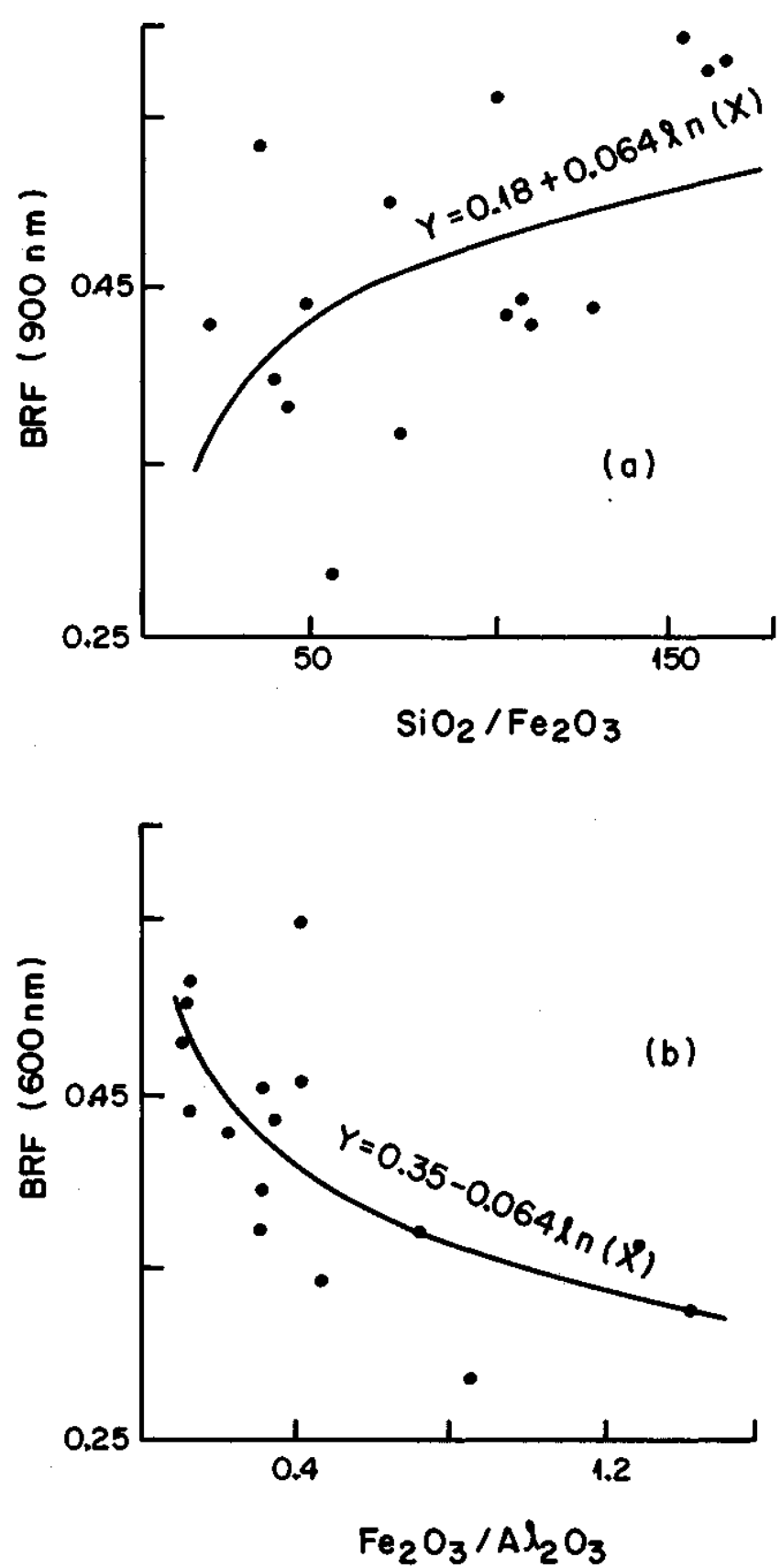

Figure 9 - Scatter diagrams for 16 sandstone samples, showing the relationship between reflectance (BRF) at 900 $\mathrm{nm}$ and $\mathrm{SiO} 2 / \mathrm{Fe}_{2} \mathrm{O}_{3}$ ratio in (a), and between BRF at $600 \mathrm{~nm}$ and $\mathrm{Fe}_{2} \mathrm{O}_{3} / \mathrm{Al}_{2} \mathrm{O}_{3}$ ratio in (b)

Figura 9- Diagrama para 16 amostras de arenitos, mostrando a rela?ao entre reflectSncia (BRF) em $900 \mathrm{~nm}$ e a razao $\mathrm{SiO}_{2} / \mathrm{Fe}_{2} \mathrm{O}_{3}$ em (a), e entre BRF em $600 \mathrm{~nm}$ e a razao $\mathrm{Fe}_{2} \mathrm{O} / \mathrm{Al}_{2} \mathrm{O}_{3} \mathrm{em}$ (b)

but indicates the compositional transition between higher reflectance sandstones (samples poor in iron, organic matter and clay fraction) and low reflectance shales (samples richer in these constituents). Considering the clay-sized fraction in each sample, indicated by the correlation between $\mathrm{SiO}_{2}$ (coarser grains) and $\mathrm{A}_{2} \mathrm{O}_{3}$ (matrix) of figure $5 \mathrm{a}$, and the grain size distribution of figure 12 , we may conclude that for an increasing amount of clay fraction, there is a corresponding decrease in reflectance or albedo. A similar effect has been observed in soils by Gerbermann \& Neher (1979), who noted that increasing amounts of sand to a clay soil increased its reflectance.

Despite the fact that the explanation for such behavior points to the increase in iron and organic matter contents, which presence is one of the reasons for the decreasing reflectance, we can make some speculations in relation to the scattering effects of grain size mixtures. At the surface, an increased content of the clay fraction would have antagonistic effects on the incident radiation. It would make a more regular surface by filling existing voids and cracks at the surface, but would also favor downward diffuse flux, because of an increase in multiple reflected light. Internally, the clays will increase packing and surface boundaries, while decreasing the back and forth length between scattering boundaries. As a consequence, multiple scattering probably increases and, by its turn, the opportunity for absorption is possibly enhanced. However, the extent of these effects has yet to be demonstrated and quantified.

There are notable differences with previous studies involving grain sizes. In our studies, we have made measurements on heterogeneous surfaces of rock specimens without destroying the physical structure of the samples, and we have investigated the grain size of materials that are non-absorbers. Previous studies have measurements done on particulate surfaces of various homogeneous grain sizes obtained by mechanical crushing of absorbing minerals and size separation by sieving (e.g., Salisbury \& Hunt 1968).

CONCLUSIONS The reflectances (BRF) obtained from terrigenous sedimentary rocks from the Parnaiba Basin diminish with the increasing content of $\mathrm{A}_{2} \mathrm{O}_{3}, \mathrm{Fe}_{2} \mathrm{O}_{3}$ and organic matter, as the rock samples vary from the light colored quartz arenites, subarkoses and silts tones to the darker colored mudstones and shales. Two major groups were recognized: 16 "sandstone" samples and 10 "shale" samples. However, our data indicate that the radiance pro-cess is far more complex than the general conclusion

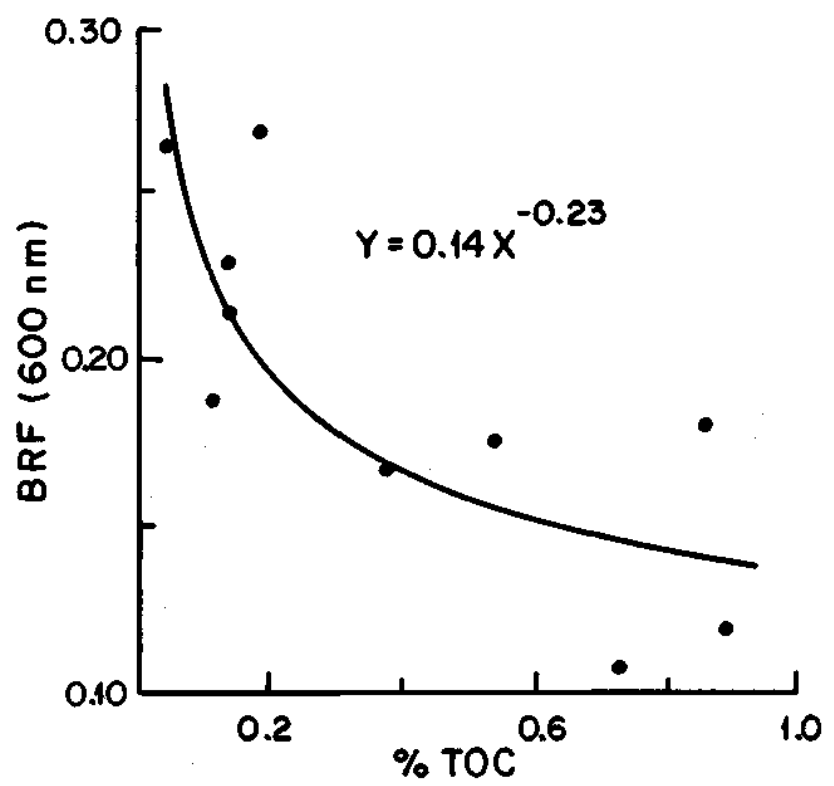

Figure 10 - Scatter diagram for 10 shale samples, presenting the association between reflectance $(B R F)$ at $600 \mathrm{~nm}$ and total organic carbon content (TOC)

Figura 10 - Diagrama para 10 amostras de folhelhos, apresentando a associate entre a reflectSncia em $600 \mathrm{~nm}$ e o conteudo de carbono organico total (TOC) 

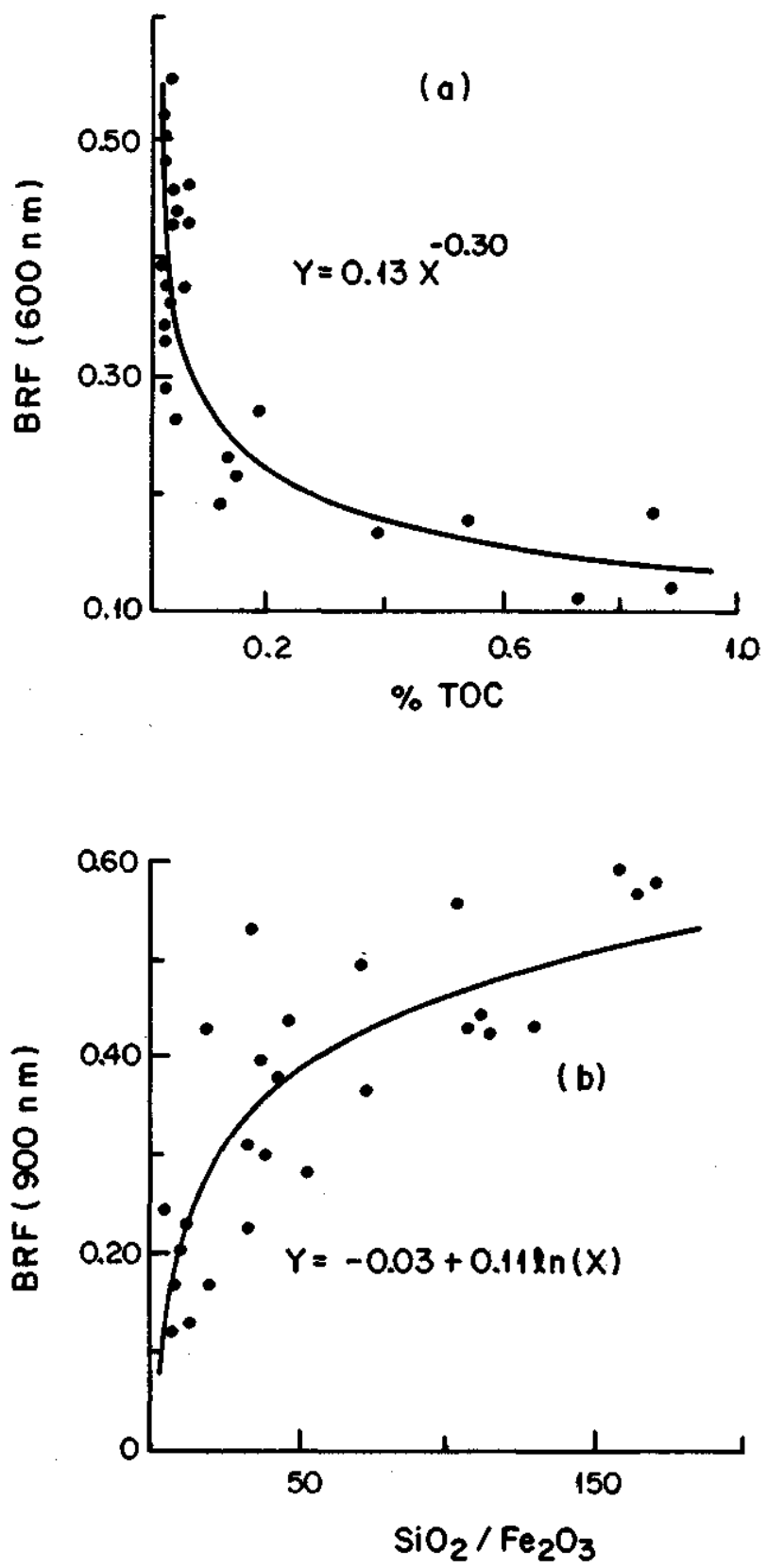

Figure 11 - Scatter diagrams for the 26 samples of sandstones and shales, showing the association between reflectance $(B R F)$ at $600 \mathrm{~nm}$ and total organic carbon content (TOC) in (a), and between BRF at $900 \mathrm{~nm}$ and $\mathrm{SiO}_{2} / \mathrm{Fe}_{2} \mathrm{O}_{3}$ ratio in (b)

Figura 11 - Diagrama para 26 amostras de arenitos e folhelhos, mostrando a associagao entre reflect§ncia (BRF) em $600 \mathrm{~nm}$ e o contetido de carbono orgânico total (TOC) em (a), e entre $\mathrm{BRF}$ em $900 \mathrm{~nm}$ e a razao $\mathrm{SiO}_{2} / \mathrm{Fe}_{2} \mathrm{O}_{3}$ em(b)

that sandstones are more reflective in the spectral interval of 400- to 2,500-nm than most shales. Reflectances increase with the content of $\mathrm{SiO}_{2}$, and of $\mathrm{SiO}_{2}$ over $\mathrm{Fe}_{2} \mathrm{O}_{3}$. However, in general, the chemical parameters have strong interdependency. In shale samples, the spectral influence of the iron in the VIS interval can be blanketed by the presence of a relatively small amount of organic carbon.

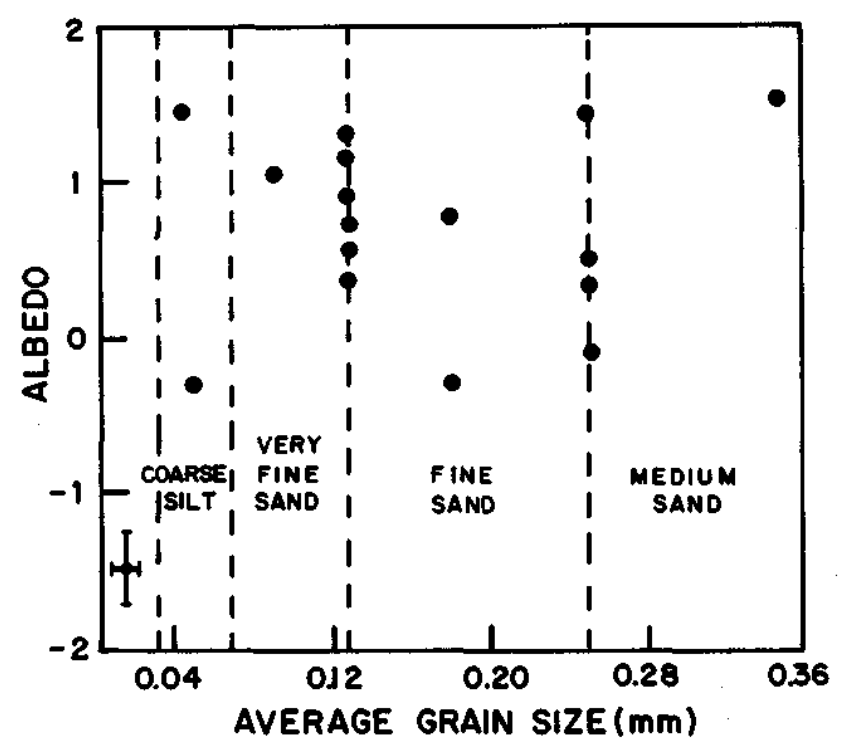

figure 12 - The variation of the albedo (overall reflectance), represented by PCI score values, as a function of the average grain size for the 16 sandstone samples. These parameters are also indicated, for the shale samples, by a mean value and the respective deviation (bars). The albedo increases towards positive PCI scores

Figura 12- Variação do albedo (reflectancia total), representada por escores 1 em função do tamanho médio dos graos de 16 amostras de arenitos. Estes parSmetros estSo também indicados para as amostras de folhelhos, através de um valor me'dio e do desvio (barras) associado. $\mathrm{O}$ albedo aumenta em direção a escores $\mathrm{PC} 1$ positives

The present work raises the question whether the observed change in reflectance is solely due to iron and organic matter absorption or whether the clay-sized fraction enhances absorption by these constituents. The possibility that an increase in clay might facilitate absorption by increasing internal flux and also the number of scattering events remains a speculation.

Recognized limitations in our present work are related to the fixed experimental geometry and gross chemical and physical analysis. Nonetheless, the study has shown the possibility of reflectance discrimination, provided the rock samples have distinct chemical characteristics. This is fundamental for the reflectance-lithostratigraphy of a sequence of rock units.

Future attempts to investigate questions raised herein will have to deal with precise determination and quantification of surface conditions (micro structures) and internal arrangement. Perhaps, empirical models of component mixing (additive or constructive technique) and of component unmixing (subtractive or destructive technique), such as by chemical removal of selective components, will suffice.

Acknowledgments $\mathrm{We}$ are grateful to Petrobras for the use of rock samples and financial support. We thank EM. Bezerra da Cunha, C.K. Chang and Paulo R. Meneses for useful discussions, Waldir R. Paradella for reviewing the manuscript, V.A. Perdiz for computational support, and an anonymous reviewer. Lenio S. Galvao was supported by a Petrobras scholarship during the period of this investigation and is supported by a CNPq scholarship. 
REFERENCES

ADAMS, J.B. \& McCORD, T.B. 1973. Vitrification darkening in the lunar highlands and identification of Descartes material at the Apollo 16 site. In: LUNAR SCIENCE CONFERENCE, 4. Houston, Texas, USA, 1973. Proceedings... New York, LPI. p. 163-177.

CLARK, R.N. \& ROUSH, T.L. 1984. Reflectance spectroscopy: quantitative analysis technique for remote sensing applications. /. Geophys. Res. Lett., 89(7):6329-6340.

CONEL, J.E.; ABRAMS, M.J.; BAIRD, K.W. 1989. Uranium-spectral discrimination of alteration phenomena in sediments. Modern Geol, $7: 115-135$.

DOLLFUS, A.; CAILTEUX, A. ; CERVELTE, B.; HUA, C.T. MANDEVILLE, J.C. 1980. Reflectance spectrophotometry extended to u.v. for terrestrial, lunar and meteoritic samples. Geochim. Cosmochim. Acta, 44:1293-1310.

GALVAO, L.S. 1994. Litoestratigrafia de Reflect\&ncia Espectral e uma Abordagem Quantitative, para Andlise de Espectros. Sao Paulo. 181 p. jTese de Doutoramento, IAG/USP).

GALVAO, L.S; VITORELLO, I; PARADELLA, WR 1994 Spectroradiometric discrimination of laterites with Principal Components Analysis. In: THEMATIC CONFERENCE ON GEOLOGIC REMOTE SENSING, 10. San Antonio, Texas, USA, 1994. Proceedings... Ann Arbor, MI, ERIM. v. 2, p. 316-325.

GERBERMANN, A.H. \& NEHER, D.D. 1979. Reflectance of varying mixtures of a clay soil and sand. Photogram. Engin. Remote Sensing, 45(8): 1145-1151.

HAPKE, B. 1981. Bidirectional reflectance spectroscopy: 1. theory. $J$. Geophys. Res., 86(4):3039-3054

HOFFMANN, H; NEUKUM, G.; JAUMANN, R. 1990. Chemical versus mineralogical influence on reflectance spectra of andesitic whole rock powders. Lunar Planet. Sci., 21:520-521.

HO VIS, W.A., Jr.; CALLAHAN, W.R. 1966. Infrared reflectance spectra of igneous rocks, tuffs and red sandstones from 0.5 to $22 \mathrm{um}$. /. Optical Soc. Am., 56(5):639-643.

HUNT, G.R. 1977. Spectral signatures of paniculate minerals in the visible and near infrared. Geophysics, 42(3):501-513.

HUNT, G.R. \& SALISBURY, J.W. 1976. Visible and near-infrared spectra of minerals and rocks: XI, sedimentary rocks. Modem Geol., 5(4):211-217.
JAUMANN, R. 1991. Spectral-chemical analysis of lunar surface materials. J. Geophys. Res., 96(E5):22793-22807.

JOHNSON, P.E.; SMITH, M.O.; TAYLOR-GEORGE, S.; ADAMS, J.B 1983. A semiempirical method for analysis of the reflectance spectra of binary mineral mixtures. J. Geophys. Res., 88(4):3557-3561.

JUDD, D.B. 1967. Terms, definitions and symbols in reflectometry. J. Optical Soc. Am., 57(4):445-452.

KOWALICK, W.S.; SABINS, F.F.; COREA, W.C.; ALAMEDA, G.K. 1991. Multispectral scanning and digital processing of well cores. In: THEMATIC CONFERENCE ON GEOLOGIC REMOTE SENSING, 8. Denver, CO, USA, 1991. Proceedings... Ann Arbor, MI, ERIM. v. 1, p. 27-29.

LANG, H.R.; BARTHOLOMEW, M.J.; GROVE, C.I.; PAYLOR, E.D. 1990. Spectral reflectance characterization (0.4 to 2.5 and 8.0 to 12.0 um) of Phanerozoic strata, Wind River Basin and southern Bighorn areas, Wyoming./. Sediment. Petrol., 60(4):504-524.

MENESES, P.R. 1986. Avaliacdo e Selefao de Bandas do Sensor "Thematic Mapper" do Landsat-5 para a Discriminacao de Rochas Carbondticas do Grupo Bambut como Subsfdio ao Mapeamento de Semi-Detalhe. Sao Paulo. 233 p. (Tese de Doutoramento, IG/USP).

ROWAN, L.C.; PAWLEWICZ, M.J.; JONES, O.D. 1992. Mapping thermal maturity in the Chaimman shale, near Eureka, Nevada, with Landsat Thematic Mapper images. AAPG Bull., 76(7):1008-1023.

SALISBURY, J.W. \& HUNT, G.R. 1968. Martian surface materials: effect of particle size on spectral behavior. Science, 161(3339):365-366.

SASAKI, K.; SATOSHI, K.; MINAMI, S. 1983. Constrained nonlinear method for estimating component spectra from multicomponent mixtures. Appl. Opt., 22(22):3599-3603.

SHERMAN, D.M. \& WAITE, T.D. 1985. Electronic spectra of Fe $\mathrm{Fe}^{3+}$ oxides and oxide hydroxides in the near IR to near UV. Am. Mineral., 70:1262-1269.

TOWNSEND, T.E. 1987. Discrimination of iron alteration minerals in visible and near-infrared reflectance data. /. Geophys. Res., 92(2):1441-1454

MANUSCRITO A765

Recebido em 29 de junho de 1993 Revisao do autor em 9 de maio de 1995 Revisao aceita em 16 de maio de 1995 